\title{
Solid waste from the hospitality industry in Cyprus
}

\author{
A. A. Zorpas ${ }^{1}$, K. Lasaridi ${ }^{2}$, I. Voukkali ${ }^{3}$, P. Loizia $^{3}$ \\ \& V. J. Inglezakis ${ }^{3}$ \\ ${ }^{I}$ Cyprus Open University, Faculty of Pure and Applied Science, \\ Environmental Conservation and Management, Nicosia, Cyprus \\ ${ }^{2}$ Harokopio University, Department of Geography, Athens, Greece \\ ${ }^{3}$ EnviTech Ltd, Institute of Environmental Technology and Sustainable \\ Development, Department of Research and Development, \\ Paralimni, Cyprus
}

\begin{abstract}
Solid waste generation and disposal is one of the most negative impacts of hotels on the environment. Hospitality industries often pay little attention to their environmental responsibilities. Solid waste is a key concern in the hospitality industry. Typically, a hotel guest can produce $1 \mathrm{~kg}$ of waste per day that accumulates to thousands of tonnes of waste annually. Many hotel operators have very little interest in reducing and/or recycling waste, believing that such activities are too expensive and time-consuming. The main objectives of this study were to provide data regarding the solid waste management from hotel and present typical practices for waste prevention / minimization at source. Keywords: hotels solid waste, prevention activities, waste minimization.
\end{abstract}

\section{Introduction}

With a rising level of prosperity in industrialized countries, an increasing number of products and services are being produced and consumed. This critical expansion is replicated in the amount of waste generated [1]. The last 30 years the total amount of municipal solid waste has been continuously increasing. In 2008 (according to the official statistics from Eurostat which was published in 2011), the total waste generation in the EU-27 was up to 2.62 billion t. This was slightly lower than in the years 2004 and 2006 where the EU-27 total amounted 
to 2.68 billion $t$ and 2.73 billion $t$ respectively. In 2008,98 million $t$ or $3.7 \%$ of the generated total were classified as hazardous waste. This means that per capita in 2008 each EU citizen produced on average about $5.2 \mathrm{t}$ of waste, of which $196 \mathrm{~kg}$ were hazardous, [2]. According to Waste Framework Directive (directive 2008/98/EC), waste prevention are the measures taken before a substance, material or product has become waste, that reduce the quantity of waste, the adverse impacts of the generated waste on environmental and human health or the content of harmful substances. The waste hierarchy has been applied as a priority order in waste prevention and management legislation and policy and prevention is addressed as its first priority. As the disposal of waste to landfills produces methane $\left(\mathrm{CH}_{4}\right)$, a stronger than carbon dioxide $\left(\mathrm{CO}_{2}\right)$ greenhouse gas, waste prevention has a positive effect on mitigating the climate change. Preventing waste means reducing the amount of waste generated, reducing the hazardous content of that waste and reducing its impact on the environment. Waste prevention includes strict avoidance of waste generation qualitative and quantitative reduction at source, and reuse of products. It does not include recycling of materials and separate waste collection [3]. Several researches on reducing the environmental impacts of the hotel industry have concentrated on larger hotels and major hotel players [4]. Nevertheless over much of the world, there are large numbers hotels. This research was designed to identify the challenges facing the hotels in implementing sustainable solid waste management (SWM) practices and to develop a best practice model for SWM in several. In Cyprus hotels are clarified from Cyprus Tourist Organization in stars (2-5 stars depended from their activities, number of rooms, variety of food etc.). The International Hotel Environmental Initiative [5] indicated that solid waste generation is considered one of the most adverse environmental impacts created by several and especially small hotels. Collectively, they produce a vast amount of waste, much of which goes to landfill. Many hotels consider their environmental responsibilities as a secondary objective [6] and take very little action to reduce their environmental impacts [7]. Landfill from waste from hotels contributes to the degradation of the environment through the pollution of groundwater resources due to the creation of leachates, and the emission of explosive gases, e.g. methane [8]. It also causes problems to the surrounding communities in the form of odour, flies, litter and noise [9].

\section{Description of the selected area. methodology}

Cyprus is situated in the north-eastern part of the Mediterranean Sea, 338 east and 358 north of the Equator. It is situated $75 \mathrm{~km}$ south of Turkey, $105 \mathrm{~km}$ west of Syria, $380 \mathrm{~km}$ north of Egypt, and $380 \mathrm{~km}$ east of Rhodes (Greece). The third largest Mediterranean island after Sicily and Sardinia, with a total population up to 900000 citizens (according to the official statistics of Interior Affairs from 2011), it has an area of $9251 \mathrm{~km}^{2}$, of which 1733 are forested. Cyprus has a record of successful economic performance, reflected in rapid growth, full employment conditions and external and internal stability, almost throughout the post-Independence period [10]. Cyprus is presented with almost 1000 hotels 
according to the Cyprus Tourist Organization (CTO, 2010). The selected area belongs to the Municipality of Paralimni which is presented with 115 hotels according to CTO (2010) and with a permanency population of almost 22000 citizens, while it has the ability to quest up to 50000-75000 tourist per day. The Municipality consists of the main economical lung of the island due to the fact that in this area there are the largest hotel resorts. In undertaking this work, the following phases have been carried out: (a) reviewed the current legal framework, policies and pending initiatives in relation Waste Management as well as conducted a Stakeholder analysis in order to firstly identify the main stakeholders and secondly to define their expectations; (b) undertaken an analysis of waste generation and disposal at each of the selected hotels through the use of a customized questionnaire for the collection of data; (c) purposed pest practices for waste minimization.

\section{Results and discussion}

The main objective of stakeholder analysis was to identify key groups, bodies and/ or individuals and secondly to define their expectations along with their level of involvement in the area of waste management. Main Stakeholder is the Cyprus Tourism Organization, followed by the Local Authorities and the Cyprus Hotel Association while the Department of Environment plays a significant rule. The methodology used to identify the legal framework, consisted of a desk study and face to face interviews. All current EU and national legislation in regards to solid waste were found on official websites (e.g. Environmental Department ED, Ministry of Agriculture -MA-, National Resources and Environment -NRE-, European Commission-EC) and reviewed so as to provide an understanding of the legal obligation hotels have in regards to solid waste management. According to the ED, MA, NRE, in Cyprus there are three pending initiatives in regards to solid waste management which includes: (i) Legislation on management of tyres; (ii) Legislation on excavation and demolition waste; (iii) Waste Framework Directive 2008/98/EC. The collection of baseline data was carried out through the use of a customised questionnaire (Table 1). The sample size consisted of 8 hotels belonging to the regions of Protaras Area (Paralimni Municipality). Both certified (2), with environmental management systems, and non-certified hotels (6) were included in the sample size. In addition, the sample size consisted of hotels with various ratings/ categories $\left(5^{*}, 4^{*}\right.$ and $\left.3^{*}\right)$. It was observed that none of the non-certified hotels has an environmental awareness program available for its employees. As a result, employees of such hotels do not get education or training regarding environmental issues for example, management of solid waste, recycling, practices for waste minimization etc. It was also observed that more than $80 \%$ of the sample size does communicate environmental efforts made, to guests and public. Concerning the seasonality of the hotels, only one is remaining open throughout the year adding to their total waste production. The others from $1 / 11$ until $1 / 4$ every year remains closed. In relation to the nationality of the majority of tourists visiting the hotels belonging to the sample 
Table 1: Data collection using the sample questioner.

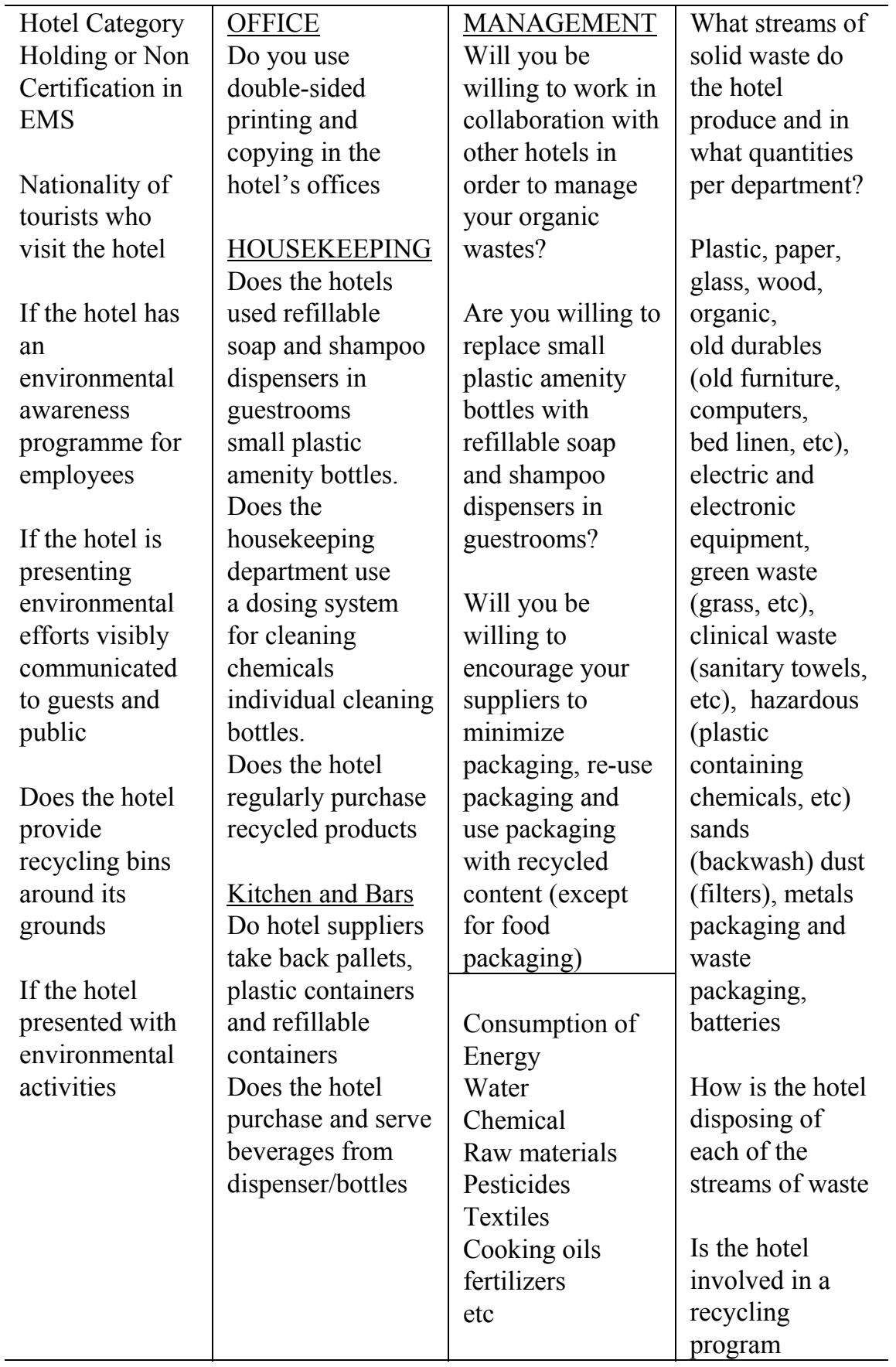


size, it was observed that they are British by up to $70 \%$ followed by Scandinavian, German, Russian and French. Nationality behaviours affect the environmental performance in each hotel.

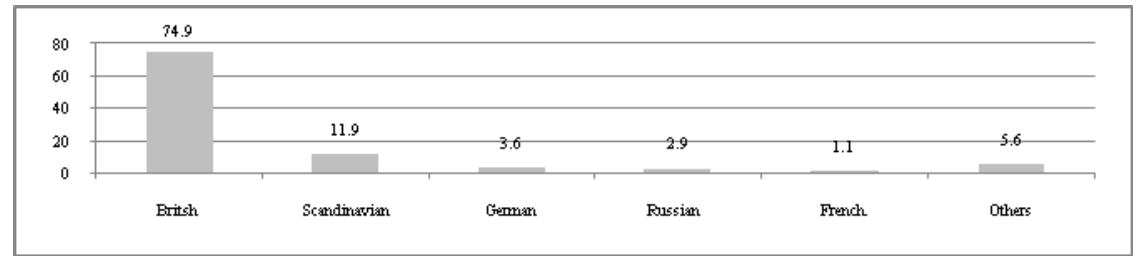

Figure 1: Nationalities presented in the hotels.

For example (according to our research), hotels that have tourists from Britain presented with high water consumption (as the water in the UK is typically free of charge) while those from Scandinavia presented with high energy consumption (due to the light nights and the fact that when they are on holiday they cannot realize that they have to switch off the lights when they go out of the room). In addition, hotels with gardens, grass, etc presented with high chemical consumption and chemical fertilizers. All the examined hotels presented with high chemical consumption regarding the pool maintenance. The main chemical that they used includes chlorine, acid and sodium base, in order to balance the pool. It was estimated that the chlorine needs per cubic, per pool and per operation day are up to $3.09 \times 10^{-4} \mathrm{Kg}$ while the Acid need is up to $1.07 \times 10^{-4} \mathrm{Kg}$. The several streams of solid waste generated by the hotels includes: Plastic, Paper, Glass, Wood, Organic (kitchen), Old durables, Electric and Electronic Equipment, Green Waste, Clinical Waste, Hazardous, Sands (from the filters of pools), Dust, Metals, Packaging and waste packaging, Batteries, Solid waste from Biological treatment, hazardous from funnels and especially from the kitchens funnels. Due to the absence of a waste measuring mechanism, the hotels were not able to provide the exact volume of waste produced per department. In order for the hotels to be able to reduce their solid wastes, they should be able to measure their waste volumes in implement waste minimization practices. As a recommendation, hotels should first incorporate a measuring mechanism in order to obtain the total volume of wastes produced. As a further recommendation, hotels should adopt appropriate measuring mechanisms in order to be able to quantify the volumes of wastes produced per department. By adopting these measuring mechanisms, hotels will be able to set more accurate and effective targets which will result to a more rational reduction of solid wastes. The various methods that each hotel uses for managing or disposing of the above streams of wastes, presented in Table 2.

Based on the results, the majority of wastes are managed or disposed by being rejected in landfills or by being recycled. Results indicated that all hotels included in the sample size are involved in a Recycling Program. The recycling program is under the responsibility of Green Dot (Cyprus) Public Co Ltd "GreenDot", the only waste stream collection scheme that exists in the country 
Table 2: Managing/disposal methods of waste streams in the examined hotels.

\begin{tabular}{|c|c|c|c|c|c|c|c|c|c|c|c|c|c|}
\hline \multirow[t]{2}{*}{$\begin{array}{l}\text { Waste } \\
\text { streams }\end{array}$} & \multicolumn{9}{|c|}{ Disposal methods } & \multicolumn{4}{|c|}{$\begin{array}{l}\text { Best implemented practices from the hotels } \\
\text { examined }\end{array}$} \\
\hline & $\mathrm{A}$ & $\mathrm{B}$ & $\mathrm{C}$ & $\mathrm{D}$ & $\mathrm{E}$ & $\mathrm{F}$ & $\mathrm{G}$ & $\mathrm{H}$ & $\mathrm{O}$ & \multirow{2}{*}{\multicolumn{4}{|c|}{$\begin{array}{l}\text { Use of refillable dispensers for soap and } \\
\text { shampoo } \\
\text { Use of dosing system instead of } \\
\text { individual cleaning bottles } \\
\text { Purchase of reusable or durable material } \\
\text { Turning the glasses in guestrooms upside } \\
\text { down instead of using plastic covers }\end{array}$}} \\
\hline Plastic & 7 & 3 & & & & & & & & & & & \\
\hline Glass & 8 & & 2 & & & & & & & \multicolumn{4}{|c|}{ Use of post mix instead of glass bottles } \\
\hline Paper & 8 & & 2 & & & & & & & \multicolumn{4}{|c|}{$\begin{array}{l}\text { Double sided printing and using one-side } \\
\text { printouts as scrap }\end{array}$} \\
\hline Wood & & & 3 & 6 & 3 & & & & 4 & \multicolumn{4}{|c|}{$\begin{array}{l}\text { Reusing as raw material for other wooden } \\
\text { products }\end{array}$} \\
\hline Organic & & & 8 & & & 4 & & & & \multicolumn{4}{|c|}{$\begin{array}{l}\text { Not identified any although they accept } \\
\text { composting }\end{array}$} \\
\hline $\begin{array}{l}\text { Old } \\
\text { Durables }\end{array}$ & & 4 & & 6 & 4 & & & & 1 & \multicolumn{4}{|c|}{ Reusing old linen as cleaning clothes } \\
\hline WEEE & 5 & & 2 & & 3 & & & 3 & & \multicolumn{4}{|c|}{ Not identified, some hotels reuse items } \\
\hline $\begin{array}{l}\text { Green } \\
\text { Waste }\end{array}$ & & & 8 & & & 2 & & & 4 & \multicolumn{4}{|c|}{ Composting and use as fertiliser } \\
\hline Clinical & 8 & & & & & 3 & & & & \multicolumn{4}{|c|}{$\begin{array}{l}\text { Not identified, some of the hotels they } \\
\text { burn them }\end{array}$} \\
\hline Hazardous & 5 & 5 & 2 & & 2 & 2 & & & & \multicolumn{4}{|c|}{$\begin{array}{l}\text { Refill (e.g. refill inkjet and toner } \\
\text { cartridges) }\end{array}$} \\
\hline Sands & & & 3 & & & & 8 & & & \multicolumn{4}{|c|}{ Not identified } \\
\hline Dust & & & & & & & 8 & & & \multicolumn{4}{|c|}{$\begin{array}{l}\text { Those who are very close to the beach } \\
\text { sent it there }\end{array}$} \\
\hline Metals & 6 & 2 & 1 & & & & & 2 & & \multicolumn{4}{|c|}{ Purchase of reusable or durable material } \\
\hline $\begin{array}{l}\text { Packaging } \\
\text { Waste }\end{array}$ & 8 & 4 & & & & & & & & \multicolumn{4}{|c|}{ Use of rechargeable batteries } \\
\hline Batteries & 8 & & & & & & & & & \multicolumn{4}{|c|}{ Recycling } \\
\hline \multicolumn{14}{|c|}{ The number indicated the number of hotels that participate in the disposal methods } \\
\hline $\begin{array}{l}\text { A: } \\
\text { Recycling }\end{array}$ & \multicolumn{3}{|c|}{$\begin{array}{l}\text { : } \\
\text { Reuse and } \\
\text { recycle }\end{array}$} & \multicolumn{2}{|c|}{$\begin{array}{l}\mathrm{C}: \\
\text { Landfill }\end{array}$} & \multicolumn{2}{|c|}{$\begin{array}{l}\text { D: } \\
\text { Burning }\end{array}$} & \multicolumn{2}{|c|}{$\begin{array}{l}\text { E: } \\
\text { Reuse }\end{array}$} & \begin{tabular}{|l} 
F: \\
Sanitary \\
land fill
\end{tabular} & \begin{tabular}{|l}
$\mathrm{G}:$ \\
Drainage \\
system
\end{tabular} & \begin{tabular}{|l|}
$\mathrm{H}:$ \\
Return to \\
supplier
\end{tabular} & $\begin{array}{l}\text { O: } \\
\text { Other }\end{array}$ \\
\hline
\end{tabular}

and consists of: PMD, Paper, and Glass. In the Municipality of Paralimni and especially in the tourist area the Green Dot established up to 80-95 recycle points giving a total amount of $(273000 \mathrm{Kg}$ from the tourist area regarding the recycle material). GreenDot cooperates with AFIS Cyprus Ltd and WEEE Electrocyclosis Cyprus Ltd which are the waste collection schemes for batteries and accumulators and for electric and electronic equipment waste, respectively. Based on the results all the examined hotels provide recycling bins around their grounds. During the research the interviewees expressed their views and personal opinions which reflect their willingness to protect the environment and how they 
Table 3: $\quad$ Waste minimization practices per department.

\begin{tabular}{|c|c|c|c|}
\hline Offices & Housekeeping & Food and beverage & $\begin{array}{l}\text { Eco purchasing guidelines } \\
\text { for energy efficient } \\
\text { equipment }\end{array}$ \\
\hline $\begin{array}{l}\text { Use a centrally- } \\
\text { placed or electronic } \\
\text { bulletin board for } \\
\text { messages instead of } \\
\text { making multiple } \\
\text { copies of memos }\end{array}$ & $\begin{array}{l}\text { Select vendors who } \\
\text { take back reusable } \\
\text { containers, pallets } \\
\text { and other waste } \\
\text { packaging }\end{array}$ & $\begin{array}{l}\text { Use only reusable } \\
\text { dishes and flatware } \\
\text { in restaurants and } \\
\text { employee cafeteria }\end{array}$ & $\begin{array}{l}\text { Purchase } \mathrm{A} / \mathrm{C} \text { equipment } \\
\text { sized for the area of use. } \\
\text { Install heat recovery units } \\
\text { on large } \mathrm{A} / \mathrm{C} \text { systems to } \\
\text { preheat water }\end{array}$ \\
\hline $\begin{array}{l}\text { Shred office paper } \\
\text { and use it to } \\
\text { package shipments }\end{array}$ & $\begin{array}{l}\text { Request that } \\
\text { manufacturers } \\
\text { package products in } \\
\text { returnable and/or } \\
\text { reusable boxes and } \\
\text { crates }\end{array}$ & $\begin{array}{l}\text { Use filters in deep } \\
\text { fryers to extend the } \\
\text { life of cooking oil }\end{array}$ & $\begin{array}{l}\text { Install lighting controls } \\
\text { (timers or occupancy } \\
\text { sensors) to turn off lights } \\
\text { in unoccupied areas such } \\
\text { as storage rooms, } \\
\text { employee rest rooms, } \\
\text { walk-in coolers, etc }\end{array}$ \\
\hline $\begin{array}{l}\text { Reuse envelopes } \\
\text { and folders for } \\
\text { routing in house } \\
\text { mail and } \\
\text { correspondence } \\
\text { Make double sided } \\
\text { copies when } \\
\text { possible }\end{array}$ & $\begin{array}{l}\text { Use refillable bath } \\
\text { soap, shampoo, hair } \\
\text { rinse and hand } \\
\text { lotion dispensers } \\
\text { for guest rooms to } \\
\text { eliminate soap } \\
\text { pieces and plastic } \\
\text { bottles }\end{array}$ & $\begin{array}{l}\text { Request fruits, } \\
\text { vegetables and } \\
\text { meats to be } \\
\text { packaged in } \\
\text { reusable crates, or } \\
\text { recyclable boxes }\end{array}$ & $\begin{array}{l}\text { Use photovoltaic lighting } \\
\text { systems for lighting } \\
\text { advertising signs, } \\
\text { walkways, plants, trees, } \\
\text { decorative water fountains } \\
\text { and remote out-door areas }\end{array}$ \\
\hline $\begin{array}{l}\text { Use electronic mail } \\
\text { for correspondence } \\
\text { when possible }\end{array}$ & $\begin{array}{l}\text { Refinish and } \\
\text { reupholster } \\
\text { damaged and dated } \\
\text { furniture }\end{array}$ & $\begin{array}{l}\text { Use glass or plastic } \\
\text { coasters to reduce } \\
\text { cocktail napkin } \\
\text { waste }\end{array}$ & $\begin{array}{l}\text { Use dishwashing } \\
\text { machines that use final } \\
\text { rinse water for the } \\
\text { prewash of the next load } \\
\text { of dishes }\end{array}$ \\
\hline $\begin{array}{l}\text { Non-toxic inks, } \\
\text { unbleached and } \\
\text { chlorine-free } \\
\text { papers, nontoxic, } \\
\text { biodegradable } \\
\text { correction fluid }\end{array}$ & $\begin{array}{l}\text { Use clothes hangers } \\
\text { left by guests for } \\
\text { employee uniforms } \\
\text { or return to the dry } \\
\text { cleaners and recycle } \\
\text { plastic garment } \\
\text { bags }\end{array}$ & $\begin{array}{l}\text { Use dry, } \\
\text { concentrated } \\
\text { dishwasher } \\
\text { chemicals in } \\
\text { dispensers to } \\
\text { reduce chemical } \\
\text { spills and waste }\end{array}$ & $\begin{array}{l}\text { Use copy and fax } \\
\text { machines which have } \\
\text { power down/stand-by } \\
\text { features that operate when } \\
\text { machines are idle }\end{array}$ \\
\hline $\begin{array}{l}\text { Equipment that } \\
\text { does not require } \\
\text { batteries, } \\
\text { rechargeable } \\
\text { batteries for small } \\
\text { calculators } \\
\text { communication } \\
\text { radios and } \\
\text { flashlights }\end{array}$ & $\begin{array}{l}\text { Purchase vacuum } \\
\text { cleaners with } \\
\text { reusable bags } \\
\text { vs. disposables ones } \\
\text { Purchase cleaning } \\
\text { products with less } \\
\text { hazardous } \\
\text { constituents }\end{array}$ & $\begin{array}{l}\text { Reduce the need } \\
\text { for pesticide } \\
\text { applications by } \\
\text { eliminating clutter } \\
\text { where pests might } \\
\text { hide; sealing cracks } \\
\text { around doors where } \\
\text { pests may enter }\end{array}$ & \\
\hline $\begin{array}{l}\text { Chart the shelf life } \\
\text { of items (i.e., toner, } \\
\text { correction fluid) } \\
\text { and purchase only } \\
\text { the needed } \\
\text { quantity }\end{array}$ & $\begin{array}{l}\text { Use a hazardous } \\
\text { chemical } \\
\text { containment pan to } \\
\text { prevent leaching of } \\
\text { unused chemicals }\end{array}$ & $\begin{array}{l}\text { Draft beer in } \\
\text { returnable/refillable } \\
\text { kegs to reduce the } \\
\text { quantity of bottles } \\
\text { and cans requiring } \\
\text { disposal }\end{array}$ & \\
\hline
\end{tabular}


will become more "Green". These views and opinions are listed below: 6 out of 8 hotels are willing to collaborate with other hotels in order to manage their organic waste; 3 of the hotels which are now using individual plastic amenity bottles for soap and shampoo are willing to replace them with dispensers; 3 of the hotels which are now using individual cleaning bottles are willing to replace them with a dosing system; all of the hotels; 6 of the hotels are willing to encourage their suppliers in order to minimise their packaging, reuse packaging or use recycled packaging; 6 of the hotels are willing to stop using plastic or paper glass covers and, instead, turn the glass upside down.

\section{Guidance's for waste minimization}

Table 3 presents a typical practice for waste minimization from selected department of the hotels. Waste prevention is one of the easiest methods of reducing waste and can be controlled at the time of purchasing products and services. There is a direct correlation between what a hotel purchases and what it throws away. However, no matter how well planned your waste reduction and recycling initiatives may be, they probably won't succeed without the support of the hotel department managers and staff. Successful hotel recycling programs require employee involvement, training and recognition. In addition, all of the resources and economic costs of materials, manufacturing, labor, transportation, packaging, storage and disposal are wasted when a product is discarded. Purchasing products made with recycled content creates outlets or markets for the materials collected in the hotel's recycling program. As such, procurement sustains the recycling process and in turn, reduces the amount of waste going to the landfill. The benefits from waste reduction can summarise to: savings through reduced purchasing costs; reduced waste disposal costs; reduced energy consumption and pollution; conservation of natural resources.

\section{Conclusion}

The United Nations World Tourism Organisation defines sustainable tourism as tourism that meets the needs of present tourists and host regions while protecting and enhancing opportunities for the future. Sustainable tourism can only be achieved if all stakeholders involved (tour operators, environmental bodies, and local authorities). Unfortunately, different organisations had different views on what sustainable tourism means as well as the existence of policies, plans and actions on waste management. The CTO operates as policy making body at the strategic level as well as a competent authority at the hospitality unit level. Local government has the responsibility to implement the waste management directions at the local level with the assistance of the approved recycling companies. With the proposed new legislation (directive 2008/98), Municipalities have a better say on the management of waste within their sphere of influence. Local government with the new legislation has the right to impose sanctions and penalties in cases where business do not conform to the stated recycling programmes. On the other hand, if the pay as you throw principle is 
adopted hospitality businesses could potentially save thousands of $€$, that could potentially finance their waste management actions. Additionally, the hotels should be able to measure solid waste reduction. For this reason, it is recommended that hotels begin to measure the total volume of waste produced. When this is achieved, the hotels are encouraged to make the measurements more specific and start quantifying the volume of waste per department. As a result, specific, measurable, achievable, realistic, time bound departmental targets can be determined for a more rational reduction of solid waste.

\section{References}

[1] Salhofer, S., Obersteiner, G., Schneider, F., Lebersorger, S., (2008) "Potentials for the prevention of municipal solid waste", Waste Management 28, 245-259.

[2] Eurostat, (2011) http://epp.eurostat.ec.europa.eu/statistics_explained /index.php/Waste_statistics (Accessed on 16 April 2012).

[3] Pre-waste, (2012) http://www.prewaste.eu/prevention-policies/item/55what-is-waste-prevention?.html (Accessed on 16 April 2012).

[4] Morrison, A. (2002) "Small hospitality businesses: Enduring or endangered?" Journal of Hospitality and Tourism Management, 9(1), 1-11.

[5] IHEI. (2002). Hotels care: Community action and responsibility for the environment. London, UK: International Hotel Environmental Initiative.

[6] Goodall, B. (1995). "Environmental auditing: A tool for assessing the environmental performance of tourism firms". Geographical Journal, 161(1), 29-37.

[7] Radwan, R.I.H., Jones, E., Minoli, D., (2010) "Managing solid waste in small hotels" 18,(2) March, 175-190.

[8] Becklake, S. (1991). Green issues thinking for the future waste disposal and recycling. London: Aladdin Books.

[9] Kharbanda, O.P., Stallworthy, E.A. (1990). Waste management: Towards a sustainable society. Farnham, UK: Gower Publishing.

[10] Zorpas, A.A., Coumi, C., Drtil, M., Voukalli, I., (2011) "Municipal Sewage Sludge Characteristics and Waste Water Treatment Plant Effectiveness under Warm Climate conditions", Desalination and Water Treatment, 36, $1-15$. 